\title{
Integrated reservoir characterization of the Paleocene Farewell Formation, Taranaki Basin, New Zealand, using petrophysical and petrographical analyses
}

\author{
Nurhazwana Jumat ${ }^{1} \cdot$ Mohamed Ragab Shalaby $^{1} \cdot$ Md. Aminul Islam $^{1}$
}

Received: 14 August 2017 / Accepted: 5 December 2017 / Published online: 13 December 2017

(c) The Author(s) 2017. This article is an open access publication

\begin{abstract}
A reservoir characterization study, using petrophysical and petrographic analyses, has been made on the Paleocene Farewell Formation in the Taranaki Basin, New Zealand, based on five selected wells. Farewell Formation is largely a sandstone formation belonging to the Kapuni Group. The integrated study has shown that Farewell Formation is a good promising reservoir with average effective porosity of $17.7 \%$ and permeability of $415 \mathrm{mD}$. The petrographic study indicates the occurrence of abundant intergranular and secondary pores. It also proved that the Farewell Formation has been affected by several diagenetic features. Compaction, cementation and clay mineral authigenesis are the most common. Quartz and feldspar overgrowths have been recorded in many samples, and secondary porosity due to dissolution is also observed. In general, good reservoir quality features are dominant in the Farewell Formation and diagenesis has little effect on the reservoir quality. These findings are supported by well log interpretation results, which confirm good sand and net pay zones are available with very low average water saturation (24.9\%).
\end{abstract}

Keywords Petrography $\cdot$ Well log $\cdot$ Petrophysical $\cdot$ Farewell formation $\cdot$ Reservoir quality

\section{Introduction}

The objective of this research is to study the reservoir quality of Farewell Formation of Taranaki Basin, New Zealand. This is carried out through a comprehensive investigation on the reservoir aspect of the Farewell Formation, via an integrated approach of petrographic and sedimentological study, as well as petrophysical aspects, which include well log interpretation. The Paleocene Farewell Formation (65-55 Ma) is the lowermost formation of the Kapuni Group and comprises mostly of fluvial sandstones. The Farewell Formation is deposited as a transgressive sequence, as a result of the regional post-rift subsidence at the end of the Upper Cretaceous. It is distributed widespread across the basin except over larger basement highs (Ministry of Business, Innovation and Employment, New Zealand 2014). In this research, the Farewell Formation reservoir quality

Mohamed Ragab Shalaby

mshalaby2004@yahoo.com

1 Department of Geology, Universiti Brunei Darussalam, Tungku Link Road, Gadong BE1410, Brunei Darussalam has been studied based on five wells, MB-R(1), MB-W(2), Amokura-1, Tui-1 and Rahi-1 wells, which are located between $173^{\circ} 00^{\prime}-74^{\circ} 00^{\prime} \mathrm{E}$ and $39^{\circ} 00^{\prime}-40^{\circ} 00^{\prime} \mathrm{S}$ on the offshore, western part of the North Island (Fig. 1).

In the study area, the Farewell Formation acts as a reservoir unit and carrier bed, where oil migration carries through and where oil accumulation is concentrated at the top of sequence. Within the area of study, the Farewell Formation unconformably overlies marginal marine strata of the uppermost Upper Cretaceous Pakawau Group (Bal 1994). The petroleum system source generated from these directly underlying Pakawau Group sediments consists of Rakopi and/or North Cape coals and organic-rich mudstones. Based on well reports, the Kapuni shale is the seal. In Amokura-1 and Tui-1 wells, this unit is $180 \mathrm{~m}$ thick, which makes it an excellent seal (New Zealand Overseas Petroleum Limited 2004).

A stratigraphic cross section between three selected wells in the Maui Field, which are MB-R(1), Rahi-1 and Maui-2 wells, has been made to show a generalized lateral extension of the Farewell Formation and other formations (Fig. 2). Within these wells, the Farewell Formation has good lateral distribution. Eahsanul Haque et al. (2016) generated a

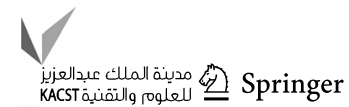




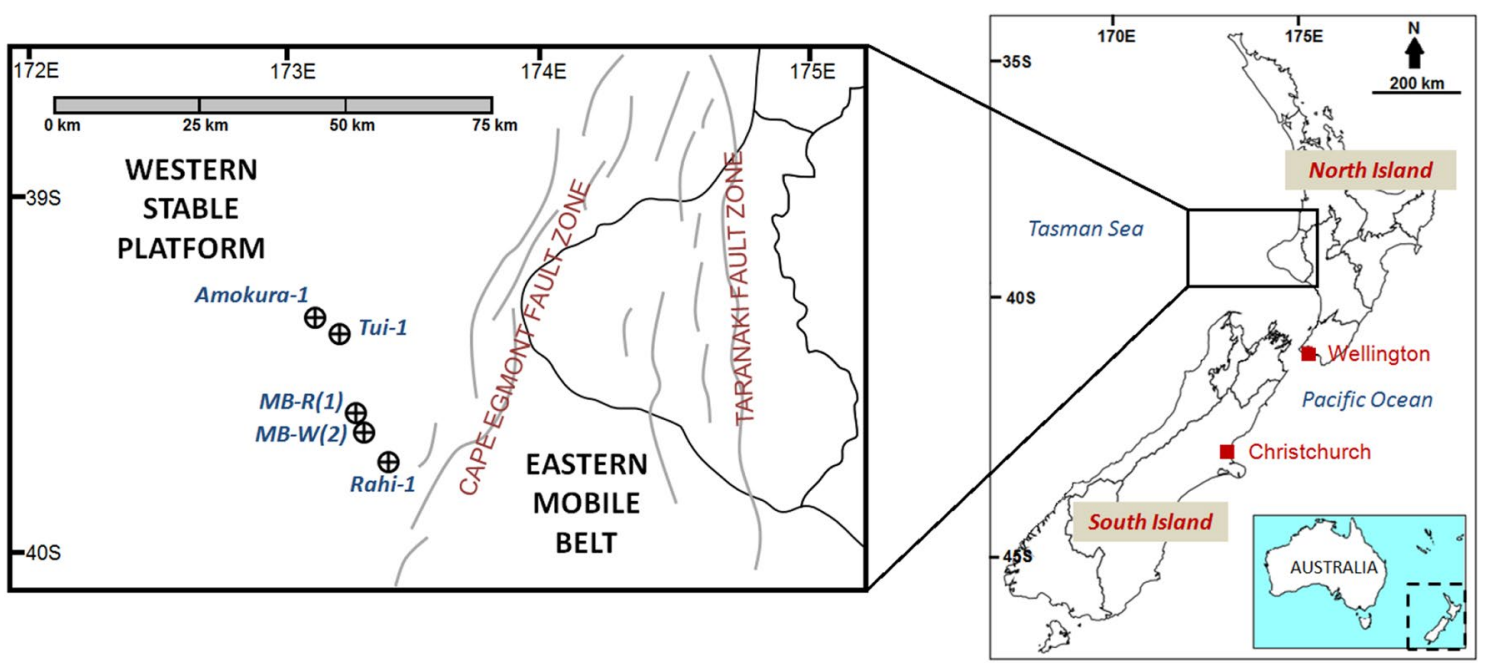

Fig. 1 Map showing the study area and well locations in Taranaki Basin, New Zealand

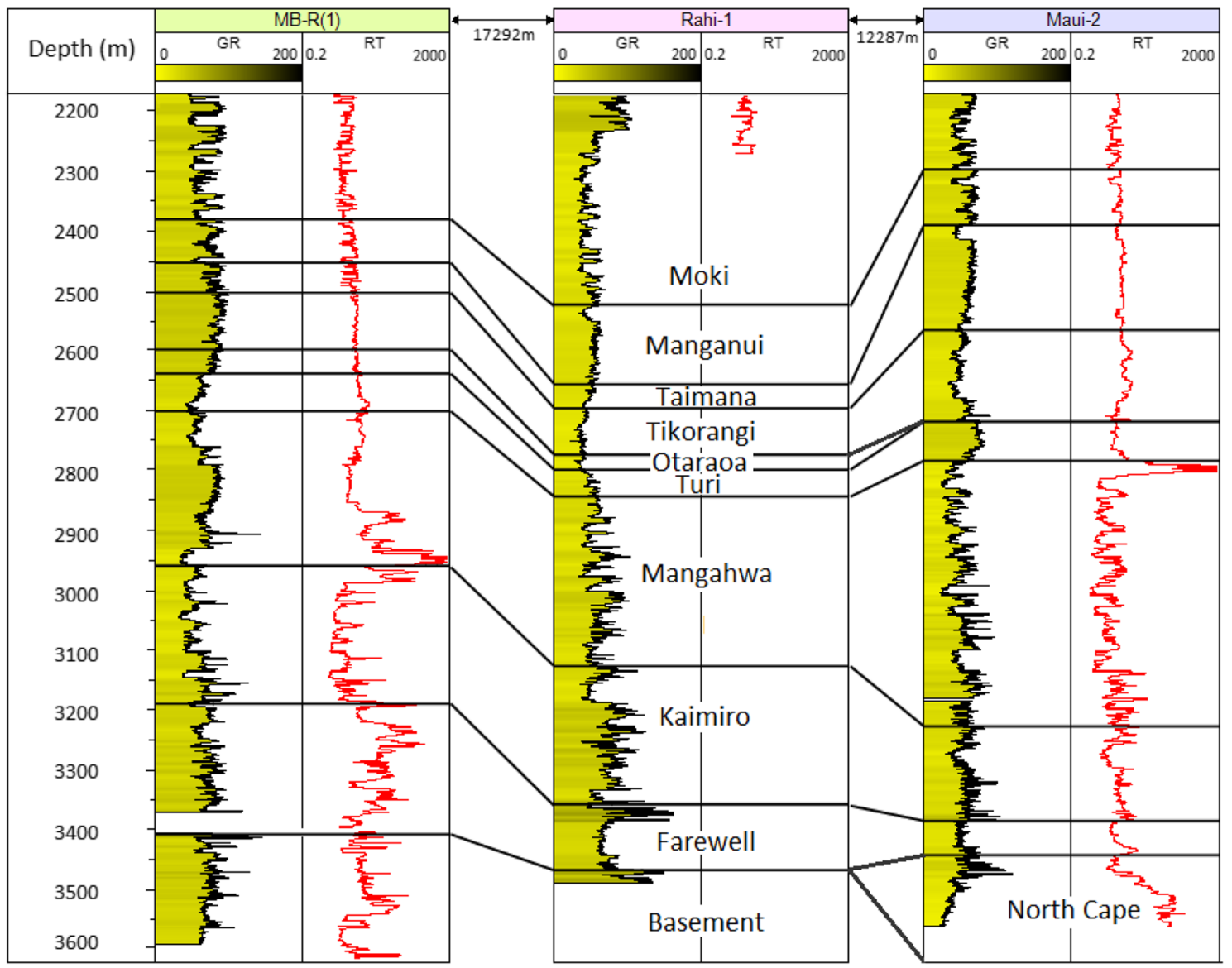

Fig. 2 Well log correlation between three selected wells which penetrated Farewell Formation in Maui Field area

structural model of the Maui field. The area is affected by a combination of extensional and inversion structure with gradual thinning of strata towards the edges of the field. A cross section showing the general structures present in the northernmost part of the field is shown in Fig. 3. 

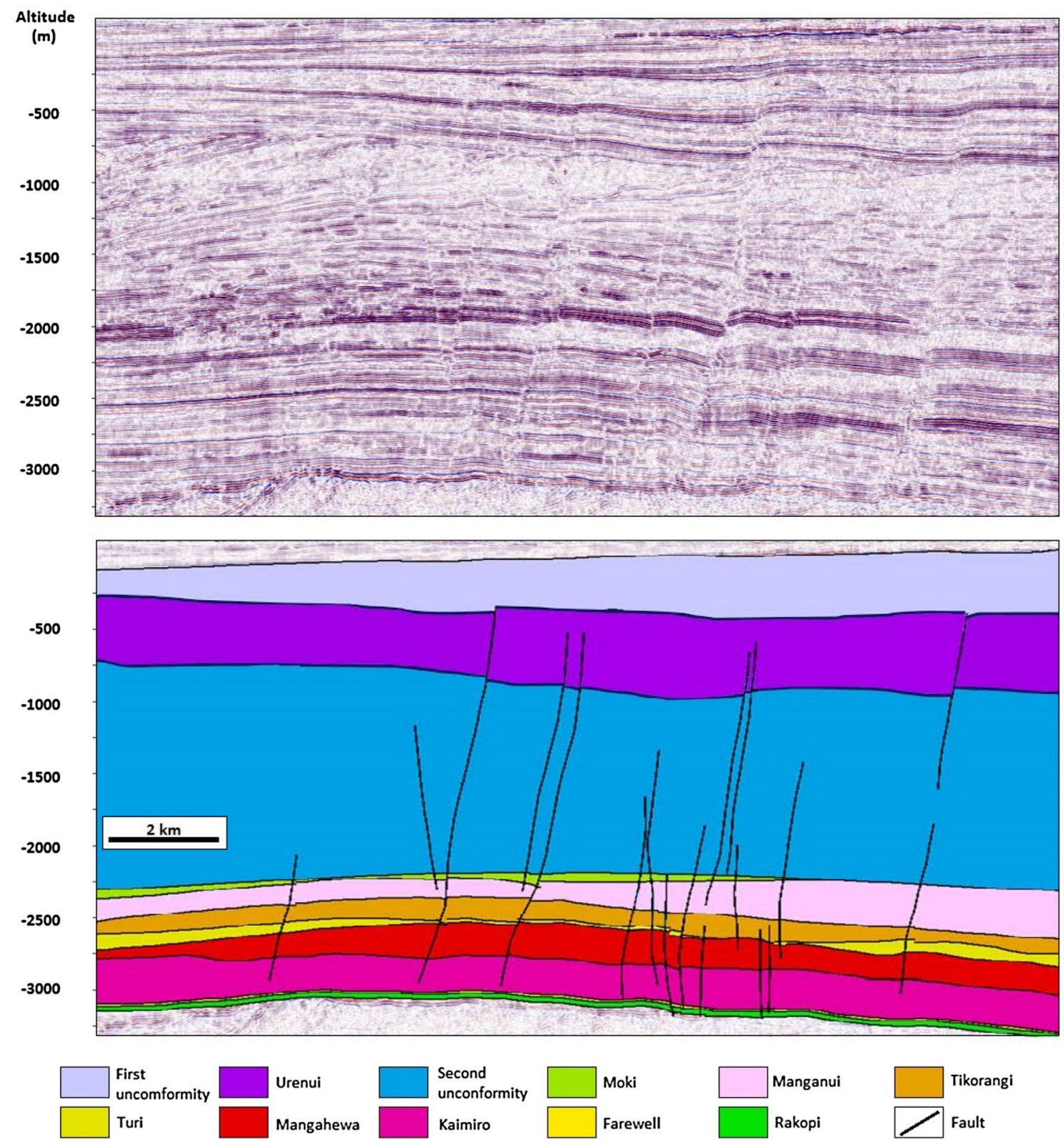

Fig. 3 Generalized fault configurations in Maui Field, modified after Eahsanul Haque et al. (2016)

This study utilizes the integrated reservoir quality study which encompasses petrophysical, sedimentological and petrographical, and well logging aspects. Similar integrated studies have been carried out previously, for example, by Hakimi et al. (2012) and Shalaby et al. (2013, 2014). Alotaby (2015) previously interpreted faults and reservoir characterization of the Farewell Formation within the Kerry Field, and Strogen et al. (2010) did a reservoir quality study of the same formation on the basis of biostratigraphy and facies development. However, this paper focuses on all three aforementioned integrated aspects of reservoir quality study.
Sandstone reservoir performance is affected by many factors including the depositional parameters of grain size and type of sorting, and diagenetic processes such as cementation and compaction (Cade et al. 1994). Whether a formation has good or poor reservoir quality largely depends on the petrophysical parameters such as porosity and permeability (Schlumberger 1989). Porosity is the amount of void spaces within a rock, which can be in-filled by hydrocarbons. Permeability is a measure of the ability of fluid to travel around the void spaces. Petrographical and sedimentological analyses help support the petrophysical findings. Of particular importance in reservoir units is diagenesis. This includes 
processes such as compaction, dissolution, clay authigenesis, cementation and mineral replacements, which contribute to physical and chemical alterations of the rocks, and may therefore enhance or impede their reservoir quality. A comprehensive understanding of reservoir quality and characterization is improved with a qualitative and quantitative well log analysis. Through well log interpretation, important petrophysical parameters such as total and effective porosities, water and hydrocarbon saturations, volume of shale and resistivity values can be achieved. Moreover, a formation can be narrowed down into reservoir and net pay zones for great analytical conclusions. Using these three analyses, the objective of this paper in achieving a thorough reservoir quality study is accomplished.

\section{Geology and lithostratigraphy}

\section{General geology}

The break-up of the supercontinent Gondwana resulted in the separation between Australia and Zealandia. This formed the Tasman Sea and numerous extensional basins on the New Zealand subcontinent, which include an intra-plate rift that formed the Taranaki Rift, which later developed into the Taranaki Basin during the late Cretaceous (Baur et al. 2014; Kroeger et al. 2013; Thrasher 1992). The Taranaki Basin evolved in three distinct phases: (1) initial rifting phase in the mid-Cretaceous-Paleocene, associated with the breakup of Gondwana, (2) Eocene-early Oligocene passive margin, post-rift thermal contraction and regional subsidence, and (3) Oligocene-recent active marginal basin in response to development of the Australia-Pacific convergent plate boundary through New Zealand (King and Thrasher 1996).

The Taranaki Basin is divided into two main structural blocks, the relatively quiescent Western Stable Platform and The Eastern Mobile Belt (Pilaar and Wakefield 1978; Knox 1982, Palmer and Geoff 1988; Armstrong et al. 1996). The Western Stable Platform, which covers the entirely offshore western part of the basin, was affected by late Cretaceous-Eocene normal block faulting but has remained relatively stable throughout the rest of the Tertiary. The Eastern Mobile Belt, on the other hand, is home to numerous tectonic processes and evolution. In the Eastern Mobile Belt, the Taranaki Basin has complex tectonic and sedimentary history that encompasses superimposed sub-basins, normal, reverse and overthrust faulting and areas of uplift.

The generalized stratigraphy for the entire Taranaki Basin consists of sediments ranging from late Cretaceous to Recent (Fig. 3). The Cretaceous-Cenozoic Taranaki Basin contains predominantly marine strata, but with significant terrestrial sedimentation occurring through the mid-Cretaceous to Eocene.

\section{Reservoir potential of Farewell Formation}

The hydrocarbons discovered in the Taranaki Basin occur in clastic and carbonate reservoir rocks of Paleocene to Pliocene ages (Fig. 3). The hydrocarbon in Paleogene reservoirs is gas-condensate, whereas Neogene reservoirs mainly trap oil (Ministry of Business, Innovation and Employment, New Zealand 2014). The Taranaki Basin reservoirs consist of a wide range of lithofacies, such as fluvial braid plain and coastal plain sandstones (Farewell Formation), shoreline and lower coastal plain sandstones (Kaimiro, Mangahewa and McKee formations), deepwater turbidite sandstones (Moki and Mount Messenger formations), volcaniclastic and epiclastic deposits (Mohakatino Formation), shelf sandstones (Matemateaonga Formation) and slope limestones (Tikorangi Formation) (King and Thrasher 1996). The formation under study is the Paleocene Farewell Formation, oldest proven reservoir sequence in the basin (Fig. 4).

Based on age and lithology, the Kapuni Group is classified into several units, from oldest to youngest: Farewell Formation, Kaimiro Formation, Mangahewa Formation and uppermost Eocene McKee Formation (King and Thrasher 1996). McKee Formation comprises of sandstones of shallow marine transgressive depositional setting, whereas the three older formations encompass a homogenous extent of laterally equivalent facies deposited across a broadly defined synchronous shoreline belt and coastal plain. Uppermost Kapuni Group strata are overlain by Turi Formation and/or Otaraoa Formation marine mudstones (King and Thrasher 1996).

\section{Data and methodology}

Data samples from MB-R(1), MB-W(2), Rahi-1, Tui-1 and Amokura-1 wells within the basin (Fig. 1) have been selected for this study. Experiments have previously been made by GNS Science, and photomicrographs, core datasets and well log data have been obtained with permission from the Ministry of Economic Development New Zealand. This research focuses on the reservoir characteristics of Farewell Formation by means of petrophysical and petrographic interpretations.

Three steps have been implemented to understand the Farewell Formation reservoir character and quality. The link between all the steps will ultimately help establish a holistic overview of the reservoir rocks.

\section{Step 1 Petrophysical analysis}

Petrophysical analysis has been carried out to investigate reservoir rock quality based on important petrophysical parameters of three wells (MB-R(1), MB-W(2) and Tui-1 


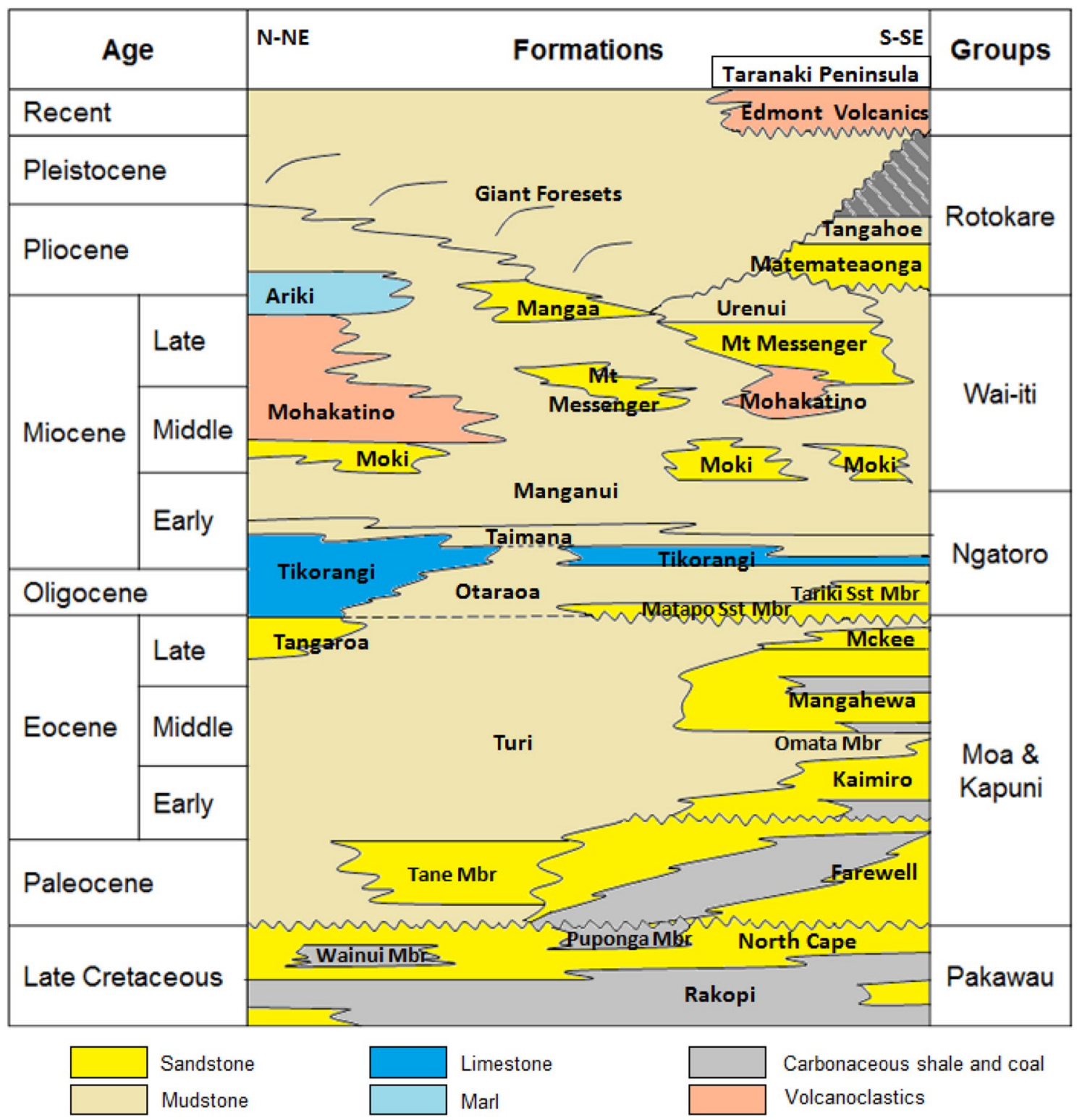

Fig. 4 Generalized chrono-stratigraphy of Taranaki Basin, modified after King and Thrasher (1996)

wells), which include porosity and permeability. 141 data points from MB-R(1) Well, 82 data points from MB-W(2) Well and 7 data points from Tui-1 Well. Statistical analysis has been made, including mean, median, mode and standard deviation, to understand the constraint they hold on the reservoir quality of the Farewell reservoir rocks. These parameters are used to classify whether the formation contains good permeability and porosity, based on the classification by Levorsen (1967).

Step 2 Sedimentological and petrographical descriptions

Photomicrographs were utilized to observe visible and distinct features and rock textures on the selected samples from MB-R(1), MB-W(2) and Tui-1 wells. Sedimentological features that make good and poor reservoir qualities are examined, such as diagenetic attributes of compaction, cementation, dissolution and recrystallization.

\section{Step 3 Well log analysis}

Log-based petrophysical analysis has been performed on the data from MB-R(1), Rahi-1, Tui-1 and Amokura-1 wells to investigate the Farewell Formation reservoir rocks and to determine the permeable beds, lithology types, fluid types, porosity and the overall hydrocarbon potentiality in the study area. In these wells, the Farewell Formation is found at the intervals 3515-3595 m (80 m thick) for MB-R(1) Well, 
3391-3471 m (80 m thick) for Rahi-1 well, 3663-3896 m (233 m thick) for Tui-1 Well and 3674-3934 m (260 m thick) for Amokura-1 Well. The log data include the conventional tools, such as the resistivity logs shallow and deep, neutron, density, sonic and gamma ray. Interactive Petrophysics developed by LR Senergy was used to carry out the qualitative and quantitative reservoir investigation. Ultimately, the important parameters such as the total and effective porosities, clay volume and water and hydrocarbon saturations are obtained. Lithology and type of clay cross-plots have been built to process the aforementioned desired output parameters of the Farewell Formation reservoir rocks.

\section{Results and discussion}

\section{Reservoir quality using petrophysical analysis}

Petrophysical analysis of Farewell Formation has been performed to study the relationship between porosity and permeability. It was observed that the porosity and permeability of the selected samples (Fig. 5) show a good positive correlation, where permeability increases with increasing porosity. Overall porosity range is between 2.5 and $28.9 \%$ (mean $16.5 \%$ ). The permeability values for all three wells are from 0.02 to $2151 \mathrm{mD}$ (mean $415 \mathrm{mD}$ ). Porosity and permeability of the Farewell Formation have been investigated through a number of histograms (Fig. 6).

MB-R(1) Well shows porosity ranges from 2.5 to $20 \%$, averaging at $15.6 \%$, while the highest majority of the data points (77\%) have porosity between 15 and $20 \%$ (Fig. 6a). The permeability for MB-R(1) Well is observed between 0.03 and $1374 \mathrm{mD}$, with a mean of $311.5 \mathrm{mD}$. The majority of the samples (68\%) have permeability values between 100 and $1000 \mathrm{mD}$.

Figure $6 \mathrm{c}, \mathrm{d}$ shows the porosity and permeability histograms for Farewell Formation in MB-W(2) Well. It has been observed that the porosity is mostly within the range of $10-22.1 \%$, with only few samples with porosity lower than $10 \%$. The majority $(49 \%)$ of the data points have porosity values between 15 and $20 \%$, while $28 \%$ have porosity in the range of $20-25 \%$ (Fig. 6c). Wide range of

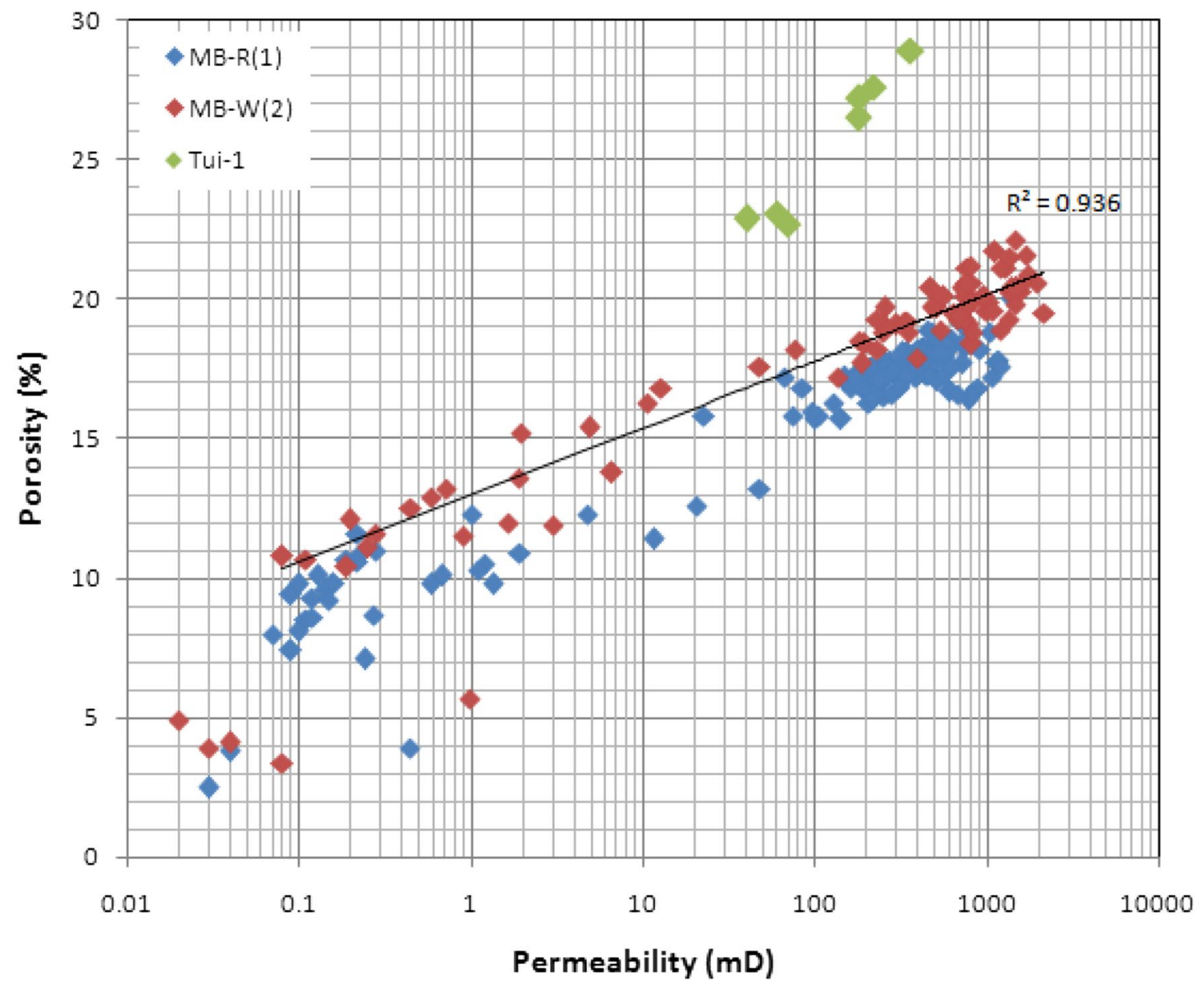

Fig. 5 Porosity-permeability relationship for the selected Farewell Formation samples shows positive trend 

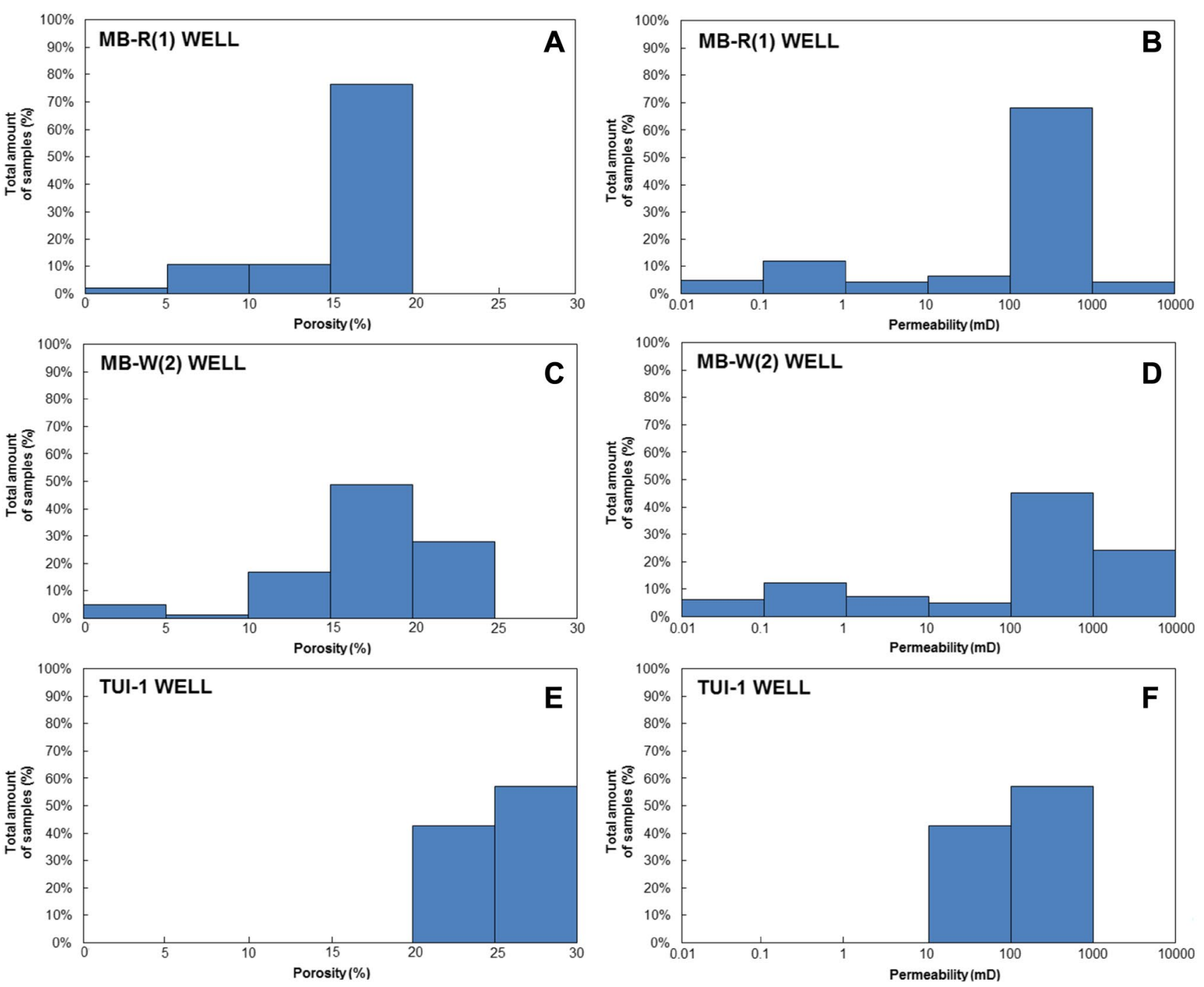

Fig. 6 Permeability and porosity histograms for MB-R(1), MB-W(2) and Tui-1 wells

permeability is observed for the studied samples from 0.02 to $2151 \mathrm{mD}$, while around $69 \%$ of the sample points have permeability above $100 \mathrm{mD}$ (Fig. 6d).

All the data points from Tui-1 Well have porosity values greater than $20 \%$ and range from 22.7 to $28.9 \%$, with a mean value of $25.6 \%$ (Fig. 6e). The permeability is also concentrated between 40 and $360 \mathrm{mD}$, averaging at $158.6 \mathrm{mD}$. All data points have permeability values above $40 \mathrm{mD}$ (Fig. 6f).

As discussed above, it is apparent that the majority of the porosity and permeability data points are above $15 \%$ and $100 \mathrm{mD}$, respectively. Based on the classification by Levorsen (1967), these values are the minimum requirements for good porosity and permeability, respectively. This indicates that the Farewell Formation has good reservoir quality, on the basis of its permeability and porosity.

\section{Reservoir quality using petrographic and sedimentological study}

In this study, the observed geological constraints on the reservoir performance Farewell sandstones include the composition and sorting of the framework grains and the diagenetic factors. However, the studied samples from the different wells show little variation in terms of framework grain composition and sorting, which largely ranges between moderately well sorted to well sorted. This suggests that diagenetic constituents may play a larger role. These include the dissolution of unstable grains resulting in porosity and the occurrences of quartz and calcite cementation and authigenic clay. Diagenetic events can change network of original pore during and after burial. 
Porosity is the dominant feature of a high-quality reservoir in the studied samples in Farewell Formation. It was observed that the sandstones of the Farewell Formation possess porosity that may be classified as a result of primary deposition or from post-deposition secondary dissolution. Based on the sample photomicrographs studied, the
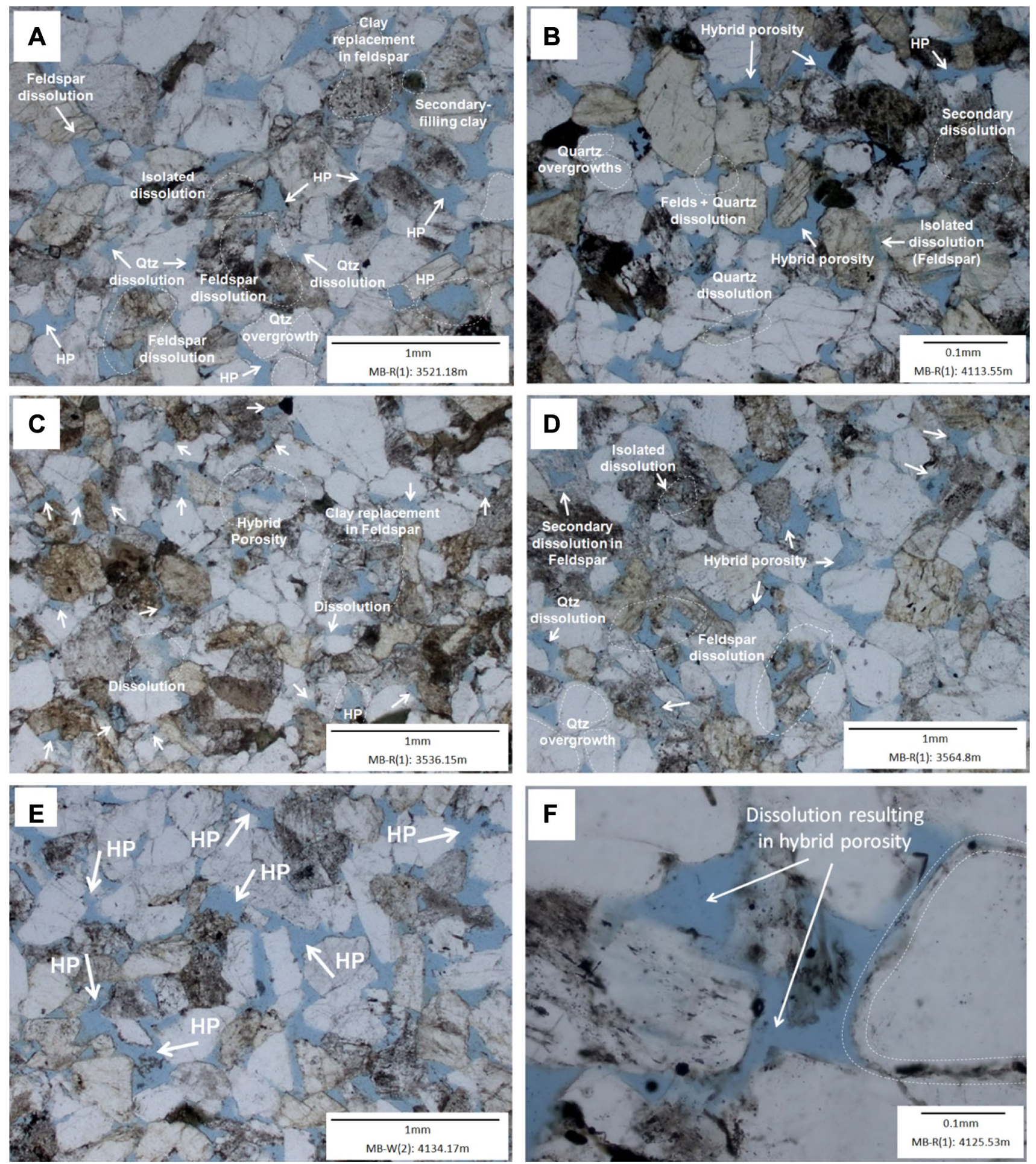

Fig. 7 Features observed in the selected Farewell Formation sample data: a-d primary intergranular porosity (stained blue), secondary dissolution in feldspar and quartz and hybrid porosity, with quartz

overgrowths, and $\mathbf{e}-\mathbf{f}$ hybrid porosity resulting from the integration of intergranular porosity and secondary dissolution porosity

$\sqrt{1}$

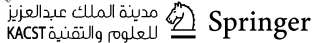



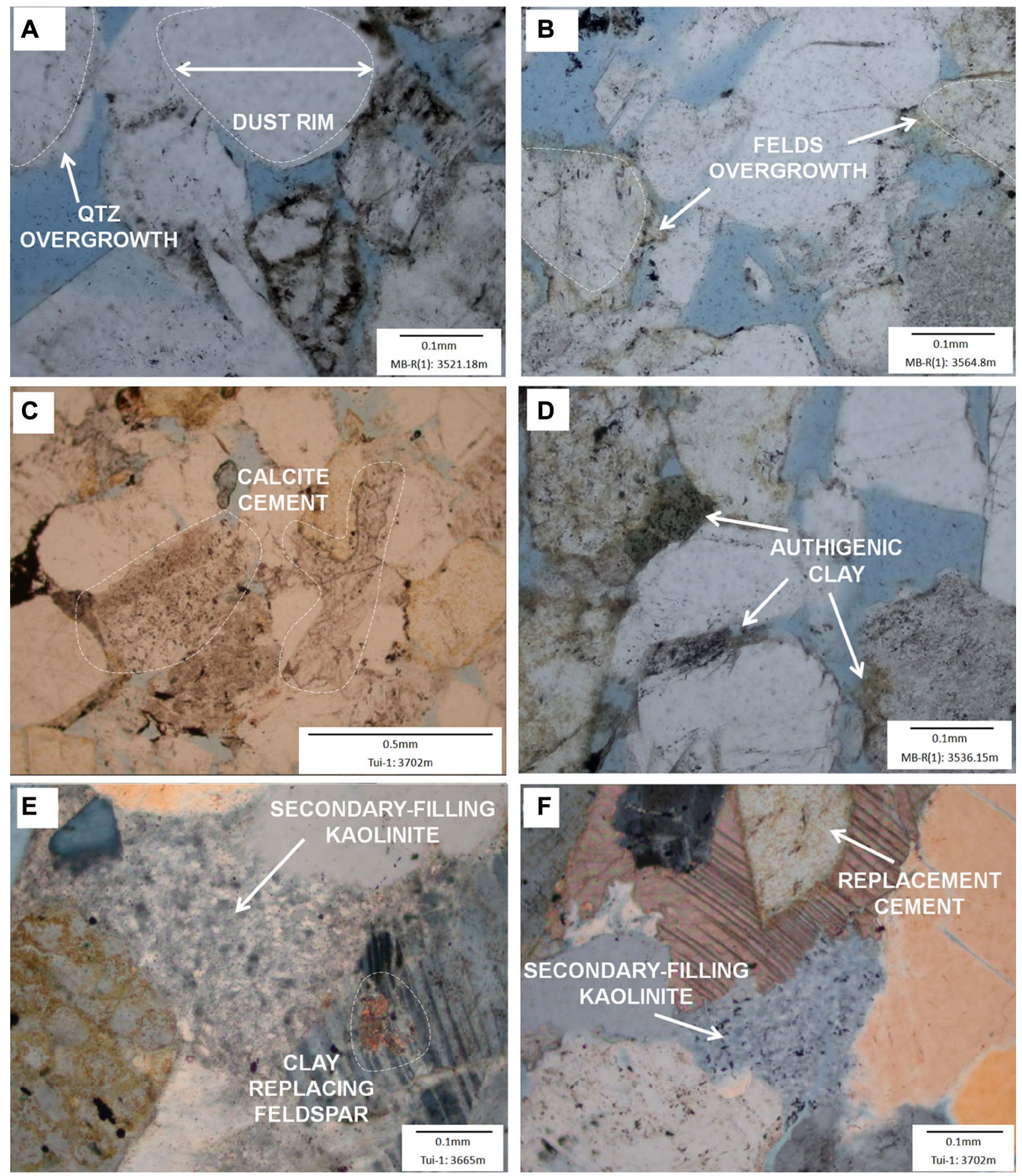

Fig. 8 Features observed in the selected Farewell Formation sample data: a quartz overgrowths with dust rims and abundant pores (intergranular, dissolution and hybrid porosity), b feldspar overgrowths and

primary and secondary porosity, $\mathbf{c}$ calcite cementation and hybrid pores, $\mathbf{d}$ authigenic clay, with large pore spaces, $\mathbf{e}, \mathbf{f}$ grain-replacive and secondary-filling clay 

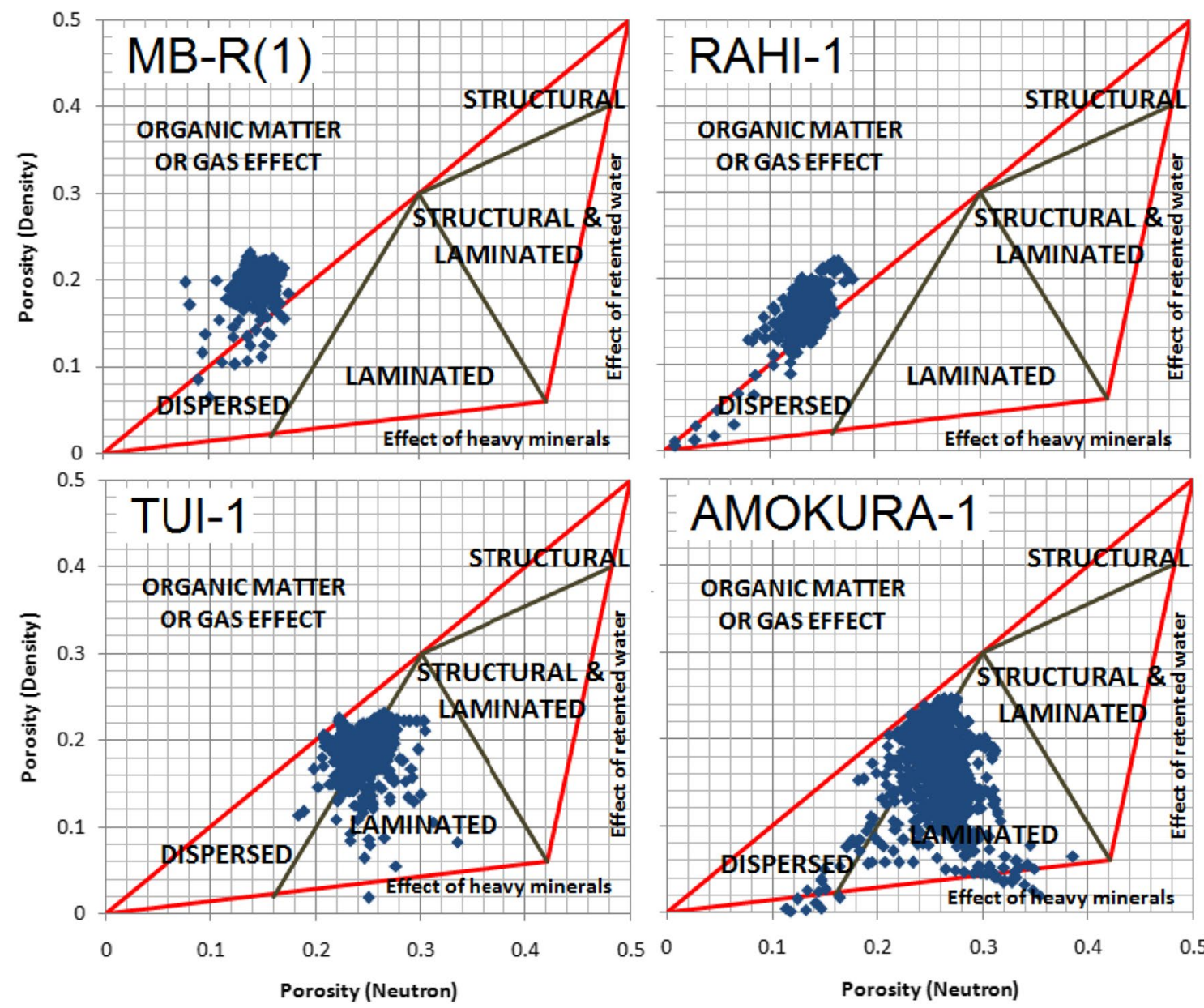

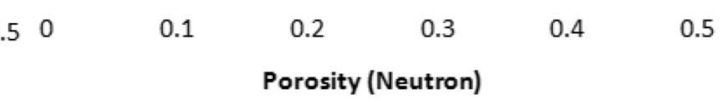

Fig. 9 Clay-type analyses for Farewell Formation for the respective wells studied

primary porosity is largely made up of intergranular megapores between framework grains (Fig. 7a-c). Due to the well-connected nature of these pores, with frequently large pore-throat diameters, they contribute to high permeability.

Secondary porosity is a common reservoir qualityenhancing diagenetic feature and is largely dependent on the dissolution of calcite cement and leaching of feldspar grains (Schmidt et al. 1979; Ehrenberg, 1990). In the studied samples, secondary dissolution occurs within unstable feldspar and quartz, but especially prominent in feldspar grains. There are two types of dissolution porosity: (1) voids that are isolated from the intergranular pore network (Fig. 7d) and (2) voids that are well connected to the intergranular pore network (Fig. 7d-f). Isolated pores can occur in two ways: (1) moldic pores, where dissolution occurs in internal areas of the grain, or (2) clay rims around the original grain isolate the dissolved pore (Loucks 2006). Permeability is an important parameter in reservoir quality performance as it is an indication of available pathways for the migration of hydrocarbon fluids in the pores. Permeability is reliant on the pore connection and the size of the pore throats. As such, isolated dissolution pore type contributes little to permeability because they are connected to the primary pore network by relatively small pore throats, regardless whether the pore itself is large, whereas non-isolated dissolution pores are better connected to the primary pore network by larger pore throats than isolated dissolution pores. The latter results in hybrid porosity (Fig. 8d-f). Hence, connected pores contribute to the enhancement of reservoir quality of the sandstone.

Cementation has an adverse effect on both porosity and permeability; as cementation increases and fills up the voids, porosity and permeability decrease. Although cementation is the primary feature that contributes to locally poor reservoir quality in Farewell Formation, the presence of authigenic clay mineral and compaction also contribute to the matter. However, these poor reservoir quality features are relatively minor and do not result in overall negative impacts on the reservoir quality of the formation.

In the Farewell reservoir photomicrographs, the main cementing agents present are silica and calcite cements. Silica cementation is in the form of syntaxial quartz overgrowths (Fig. 8a), a cementing agent feature that binds 

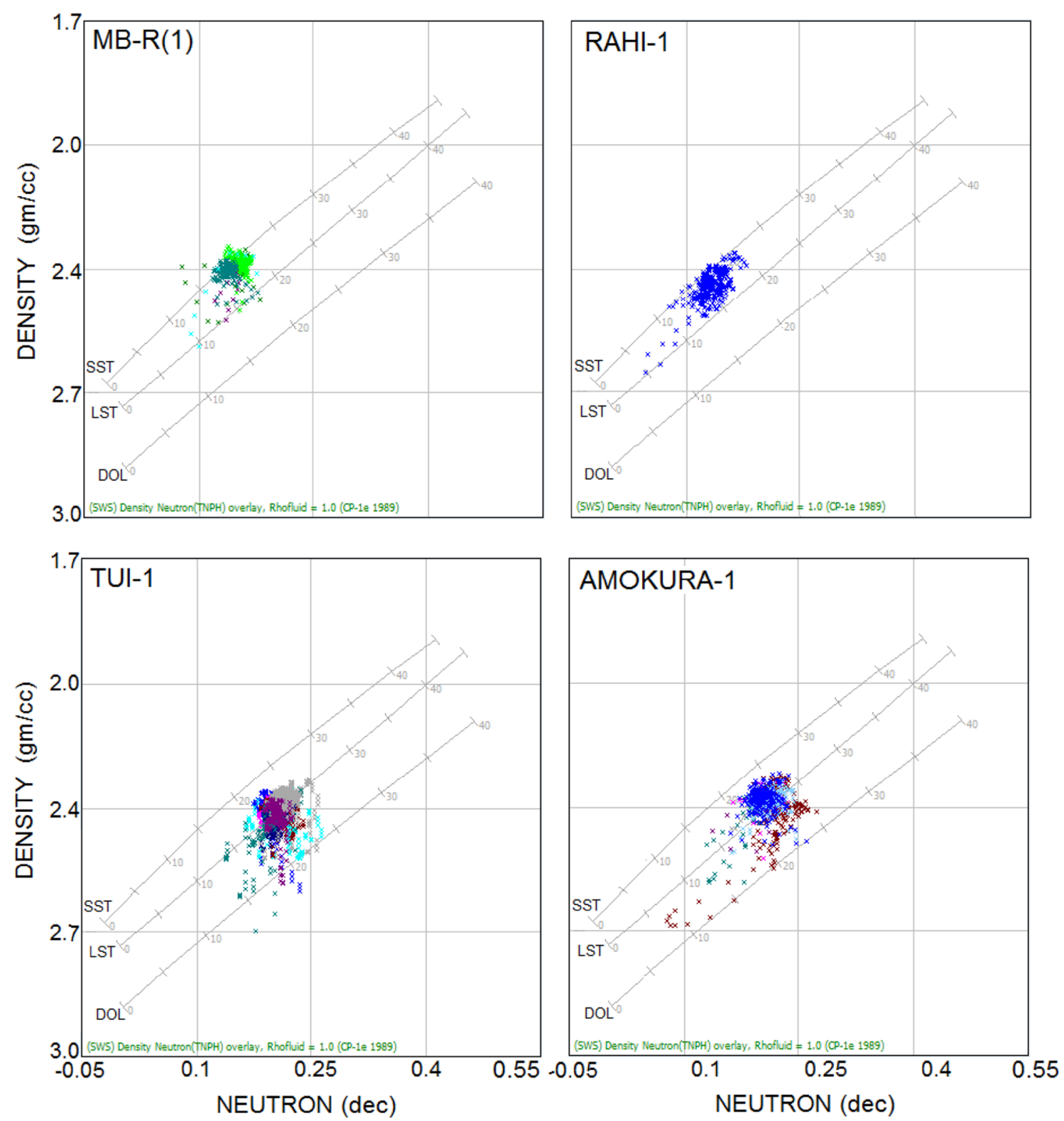

Fig. 10 Lithology analyses of the reservoir zones in the Farewell Formation from the four respective wells based on neutron-density cross-plots

Table 1 Well log petrophysical report of Farewell Formation

\begin{tabular}{|c|c|c|c|c|c|c|c|c|c|c|}
\hline \multirow[t]{2}{*}{ Well } & \multicolumn{5}{|c|}{ Thickness/Net (m) } & \multicolumn{3}{|c|}{ Porosity (\%) } & \multicolumn{2}{|c|}{ Fluids (\%) } \\
\hline & Top & Bottom & Thickness & Net Reservoir & Net Pay & PHIT & PHIE & $\mathrm{V}_{\mathrm{sh}}$ & $\mathrm{S}_{\mathrm{w}}$ & $\mathrm{S}_{\mathrm{h}}$ \\
\hline MB-R(1) & 3515 & 3595 & 80 & 31.17 & 27.74 & 19.4 & 14 & 23.7 & 23.6 & 76.4 \\
\hline Rahi-1 & 3392 & 3468.6 & 53 & 18.29 & 0 & - & - & - & - & - \\
\hline Tui-1 & 3663.5 & 3896 & 232.5 & 8.85 & 9.3 & 20.6 & 19.9 & 3.2 & 28.5 & 71.5 \\
\hline Amokura-1 & 3674 & 3934.3 & 260.3 & 132.97 & 9.59 & 20.7 & 19.2 & 7.6 & 22.6 & 77.4 \\
\hline Average & & & & & & 20.2 & 17.7 & 11.5 & 24.9 & 75.1 \\
\hline
\end{tabular}

Cut-offs used for net pay Phi $<10 \%, \mathrm{~V}_{\mathrm{sh}}<50 \%, \mathrm{~S}_{\mathrm{w}}<50 \%$

PHIT total porosity, PHIE effective porosity, $S w$ water saturation, $S h c$ hydrocarbon saturation 

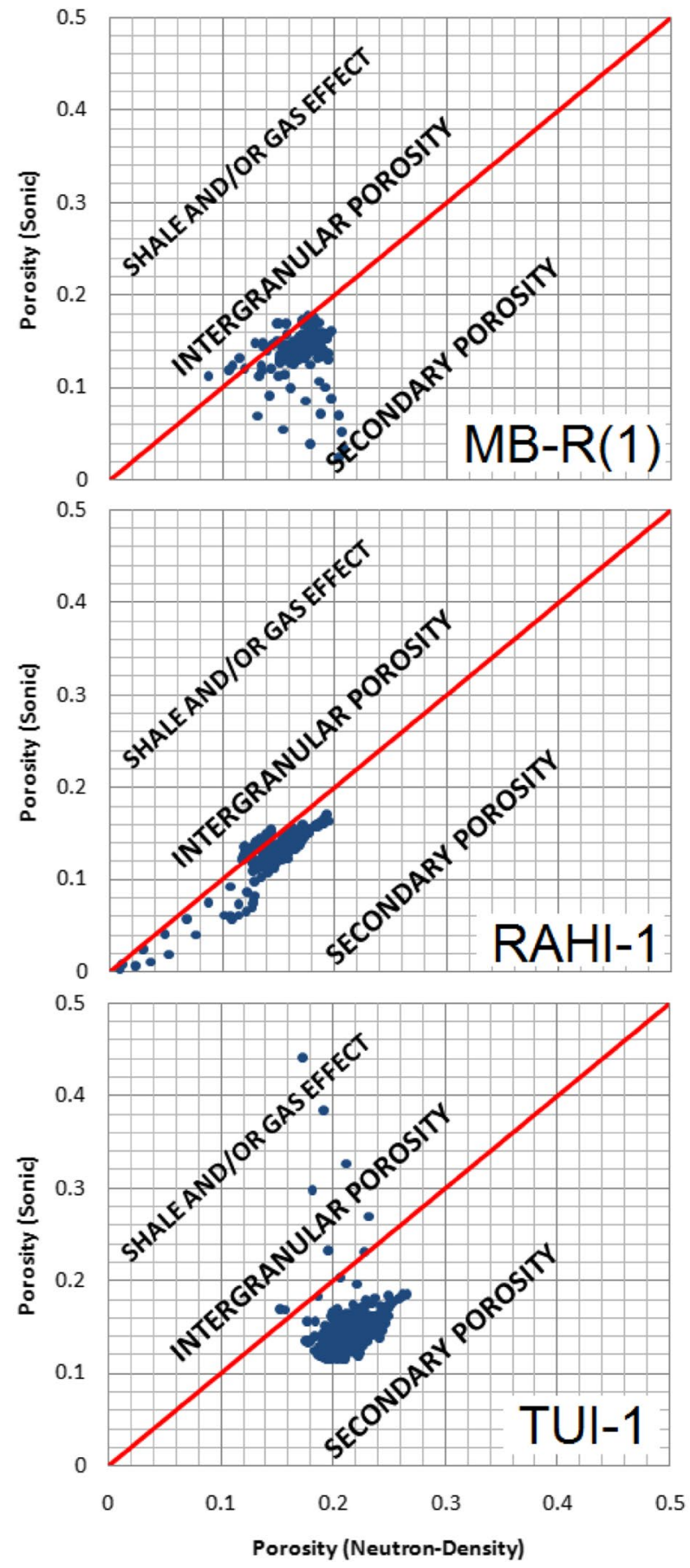

Fig. 11 Total porosity type for the Farewell Formation sandstones MB-R(1) Well log interpretation showing three pay zones with Zone 3 as the most promising zone

quartz grains together and effectively reduces existing pore spaces. Quartz overgrowths tend to grow in equant crystal shapes and are separated from detrital grains by a dust rim. They are an important reservoir quality-deteriorating mechanism in many deep petroleum reservoirs (Worden and Morad 2000) and are a major reason for decreasing porosity in many petroleum reservoirs in moderately to deeply buried sandstone reservoirs (Imam 1986; Worden and Morad 2003). In the studied samples, the quartz overgrowths coating the detrital quartz grains results in the reduction of pore diameter and consequently decreases the porosity and permeability. Calcite and quartz cements commonly coexist in sandstones and may show evidence of replacement of one mineral by the other. Changes in $\mathrm{pH}$ may cause solution of one phase and precipitation of another (Blatt et al. 1980). The solubility of silica is unaffected by $\mathrm{pH}$ values below about 9 , whereas calcite is very soluble in acidic solutions. In Fig. 8c, silica is seen being replaced by calcite cementation. This is indicative of non-acidic conditions in Tui-1 Well. Feldspar overgrowths are also present in the studied samples shown in Fig. 8b.

Clay minerals commonly sit between grains, effectively filling in the pore throats in the process. Authigenic clay minerals can become a very significant pore-blocking mechanism and may act as a cementing agent when present in an abundant amount. Clay particles act in three ways: they may completely fill a pore space, partially fill it or simply grow on its edges (pore-lining clay). In Fig. 8d-f, the clay particles act as secondary pore-filling and pore-lining clay. In Fig. 8d-f, clay becomes a replacing agent in minerals.

When there is advanced compaction, the important reservoir quality parameters such as porosity and permeability become impeded. However, collectively, the available samples studied show that the Farewell Formation is not largely affected by compaction and porosity features dominate the samples. Overall, these poor-quality features produced by diagenetic effects occur locally and are less prominent relative to the common and abundant intergranular, secondary and hybrid pores. This results in generally good reservoir quality of the Farewell Formation under study.

\section{Reservoir quality using well log interpretation}

Based on well log analyses of the four drilled wells under study, the Paleocene Farewell Formation shows promising results for a great reservoir quality. The main target of well $\log$ analysis is to evaluate the hydrocarbon potentiality of the reservoir units.

Clay volume interpretation is the foremost important step in well log evaluation. The volume is calculated using single-clay gamma ray and resistivity indicators and doubleclay neutron and density indicators. The lowest volume of shale is taken as the most optimum clay volume (Schlumberger 1989). The clay type is determined from the neutron porosity against density porosity cross-plot (Fig. 9). While laminated clay is more complex and considered part of rock structure due to their position within the sandstone rocks, dispersed clay is only subjected to the formation fluid pressure and therefore has higher porosity and water content 


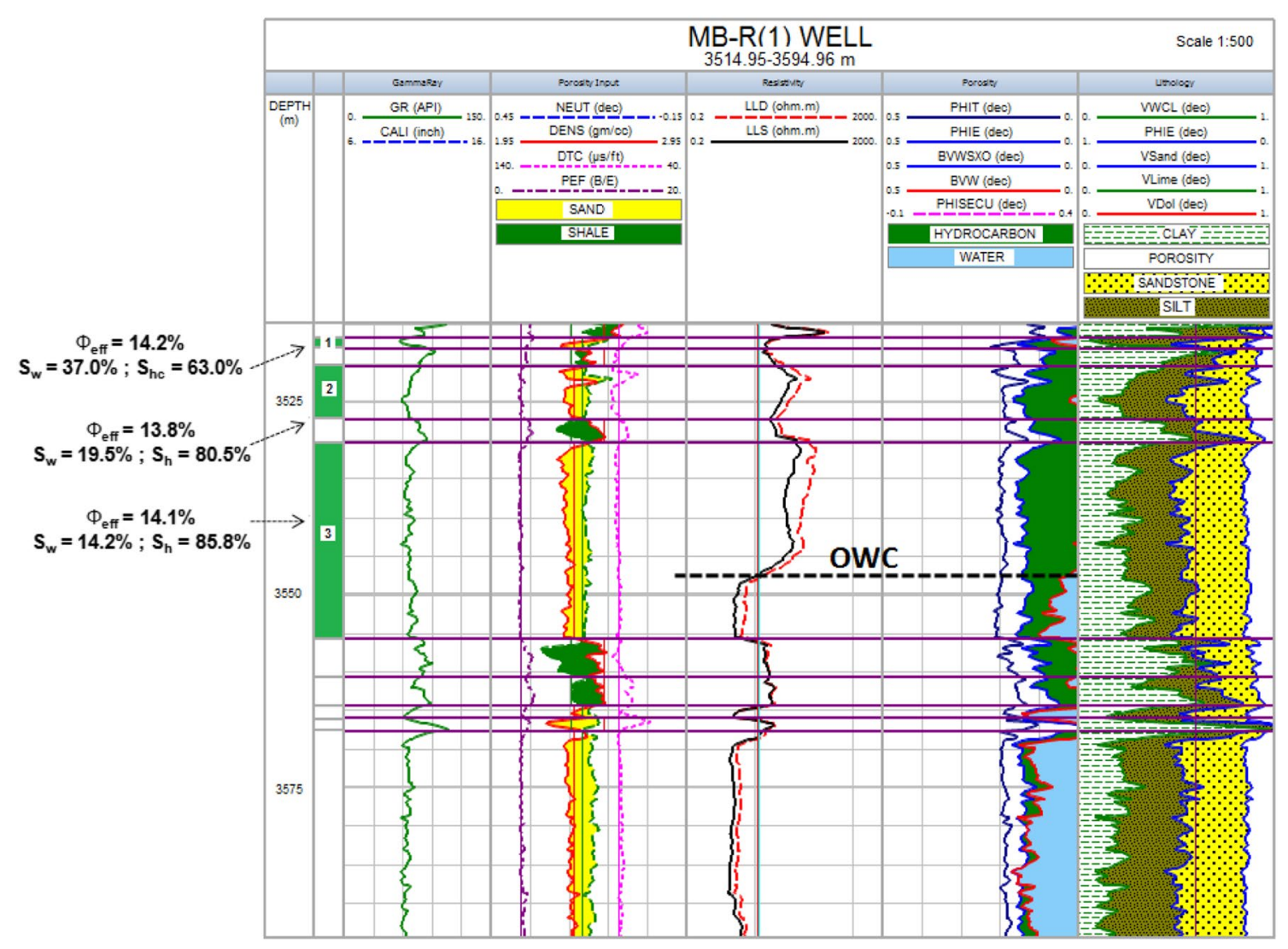

Fig. 12 MB-R(1) Well log interpretation showing three pay zones with Zone 3 as the most promising zone

(Schlumberger 1989). This affects the effective porosity of the samples. Simultaneously, the conductive shales reduce the formation resistivity, and, if not corrected for, the hydrocarbon volume calculated. Based on their clay type, the respective wells are subjected to either dual water (dispersed clay) or simandoux (laminated clay) saturation model. According to Fig. 9, data points from MB-R(1) and Rahi-1 wells are in the dispersed clay zone, whereas Tui-1 and Amokura-1 wells consist of more laminated clays.

Neutron-density cross-plots (Fig. 10) have been applied for all wells to identify the porosity and lithology. Rahi-1 and MB-R(1) wells indicate mostly sandstone lithology, whereas Tui-1 and Amokura-1 wells have a wider range of lithology besides sandstone. The latter may be an effect of greater density due to the presence of denser materials, such as silt and clay. Based on the well reports provided by GNS Science and the previously discussed photomicrograph analyses, the Farewell Formation is largely a sandstone formation with siltstone, shale and coal layers. The presence of these denser materials is shown in the photomicrographs in Fig. 6. Cementation can particularly be seen in Tui-1 Well (Fig. 8c-f).

The Farewell Formation total porosity ranges from 19.4 to $20.7 \%$, averaging at $20.2 \%$ (Table 1 ). The total porosity type is determined by applying the sonic versus neutron-density porosity cross-plots (Fig. 11). It can be seen that MB-R(1) and Tui-1 wells are largely secondary porosity type, whereas Rahi-1 Well is more evenly distributed between primary and secondary porosity. The presence of abundant secondary porosity is observed in Fig. 5. Due to unavailable sonic porosity well log readings, the crossplot cannot be applied in the case of Amokura-1 Well. The volume of clay present is between 7.6 and $23.7 \%$, with an average of $11.5 \%$ (Table 1). While there is an apparent clay effect, the effective porosity is still relatively good, where the porosity is from 14.0 to $19.9 \%$, with a mean value of $17.7 \%$ (Table 1). The Farewell Formation shows low water saturation, with the lowest at $22.6 \%$ and highest at $28.5 \%$, at an average value of $24.9 \%$. Thus, hydrocarbon saturation is high with a mean value of $75.1 \%$ (Table 1). It has been observed that the porosity obtained from well log analysis is in good agreement and correlation with that obtained from the core samples in the lab.

There are three pay zones found in the MB-R(1) Well (Fig. 12): Zone 1 is from 3516.8 to $3518.2 \mathrm{~m}$ (1.8 $\mathrm{m}$ thick), Zone 2 is from 3520.4 to $3527.3 \mathrm{~m}$ ( $6.9 \mathrm{~m}$ thick), and Zone 3 is between 3530.4 and $3555.8 \mathrm{~m}$ ( $25.4 \mathrm{~m}$ thick). All three zones show low gamma ray readings and good negative 


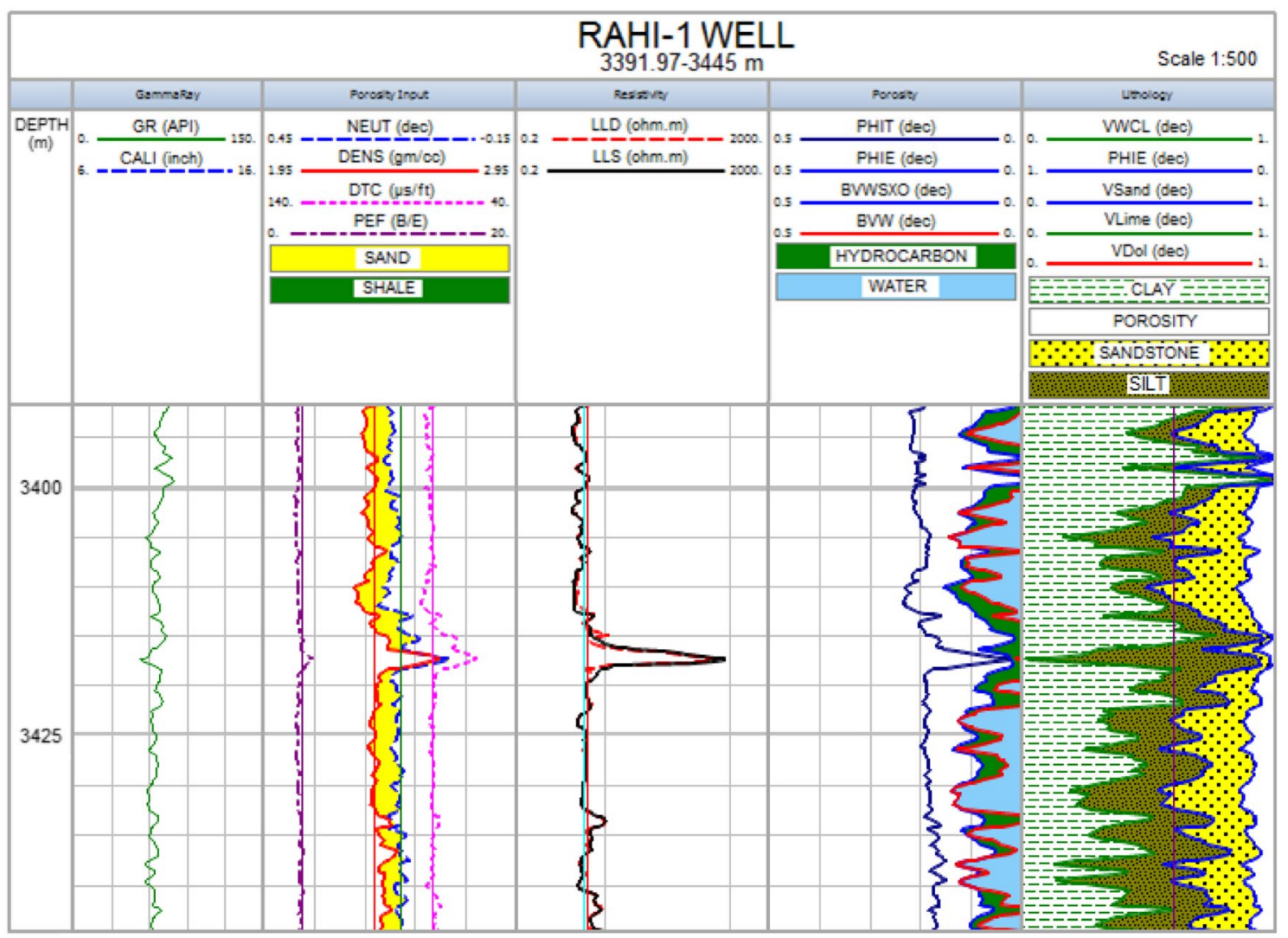

Fig. 13 Rahi-1 Well log interpretation shows no promising pay zones, and the Farewell Formation under study is water-bearing with low resistivity readings

separation between neutron and density porosity values. In terms of laterolog resistivity readings, the overall resistivity is relatively high with some separation. The most promising zone in MB-R(1) Well is Zone 3, where the resistivity separation is the biggest, with low water saturation of $14.2 \%$ and high hydrocarbon saturation value of $85.8 \%$, and a good effective porosity of $14.1 \%$. The oil-water contact (OWC) is noticed at $3547 \mathrm{~m}$, where the resistivity values decrease greatly moving into the water zone. A large sand zone interval fully occupied by water is observed at the bottom of the formation from $3569 \mathrm{~m}$.

The Farewell Formation in Rahi-1 Well (Fig. 13) has relatively low gamma ray readings, with good negative separation between neutron and density parameters. However, the resistivity is low and has no separation. The Farewell Formation in Rahi-1 Well is located in the water zone, and it is a fully water-bearing formation.

There is only a single pay zone in Tui-1 Well (Fig. 14), which is at the top of interval between 3663.5 and $3692.19 \mathrm{~m}$, which has a thickness of $28.69 \mathrm{~m}$. The gamma ray reading is relatively low. In the interval shallower than the OWC observed at $3674 \mathrm{~m}$, there is an apparent high resistivity with good separation. The effective porosity is
$19.9 \%$, showing good agreement with petrophysical results from rock samples, and water saturation is low at $28.5 \%$ with good hydrocarbon saturation of $71.5 \%$.

Pay zone in Amokura-1 Well (Fig. 15) ranges from 3674 to $3712.77 \mathrm{~m}$, with a total thickness of $38.77 \mathrm{~m}$. It is characterized by good low gamma ray readings and high resistivity with good separation at the interval shallower than the OWC at $3686 \mathrm{~m}$. The rest of the Farewell Formation beyond this point is water-bearing. The effective porosity and low water saturation values are 19.2 and $22.6 \%$, respectively. Hence, hydrocarbon saturation is very good at $77.4 \%$.

The most promising well in terms of effective porosity and hydrocarbon saturation values is MB-R(1) well. It has the best net pay thickness of $27.7 \mathrm{~m}$, with average effective porosity and hydrocarbon saturation values of 14 and $76.4 \%$, respectively (Table 1).

\section{General discussion}

Depositional environments are essential in the performance of a reservoir as they have a dominant influence on the original pore network of newly deposited sediments. The 


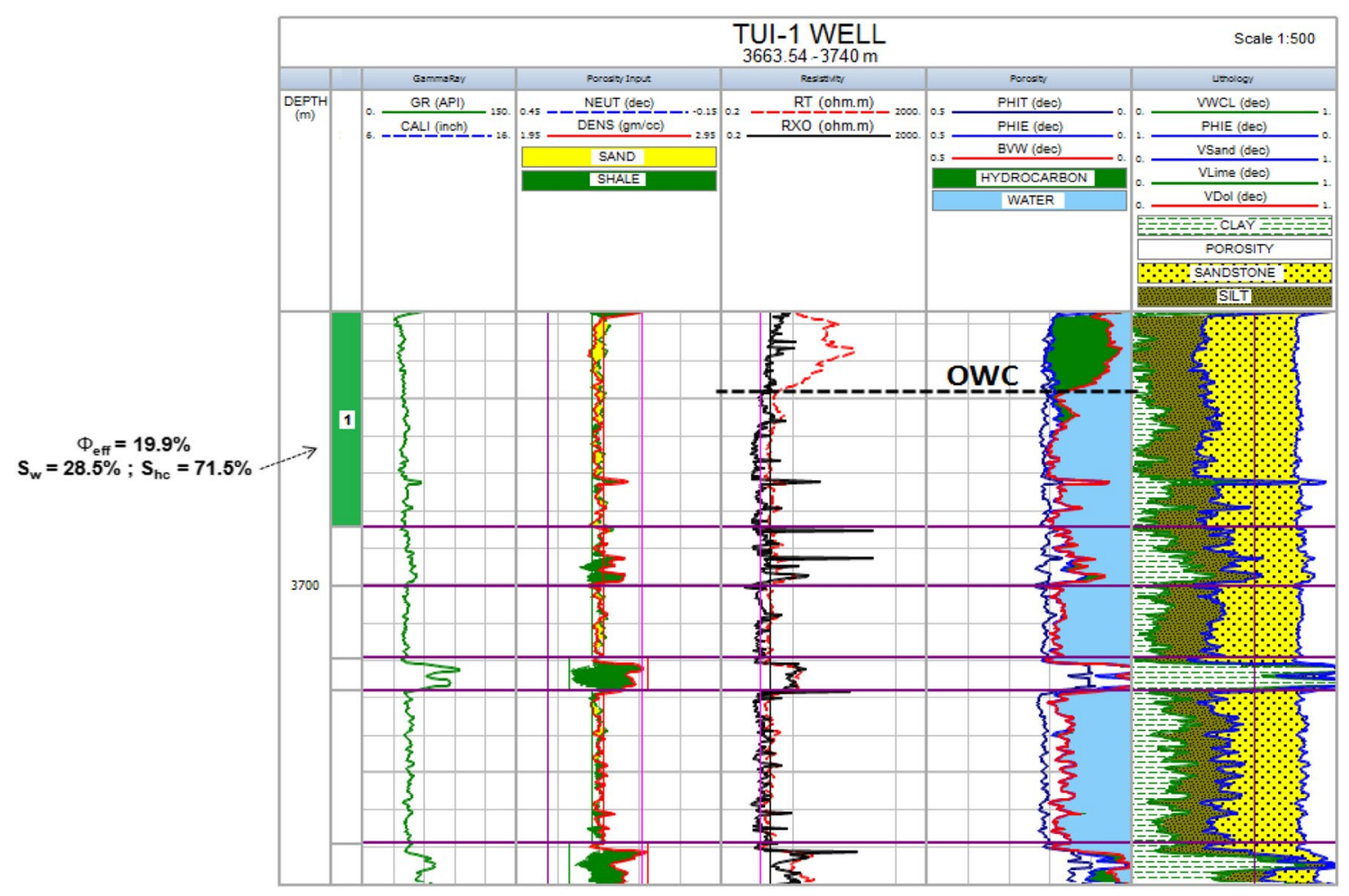

Fig. 14 Tui-1 Well log interpretation produces one promising pay zone, which has good resistivity readings

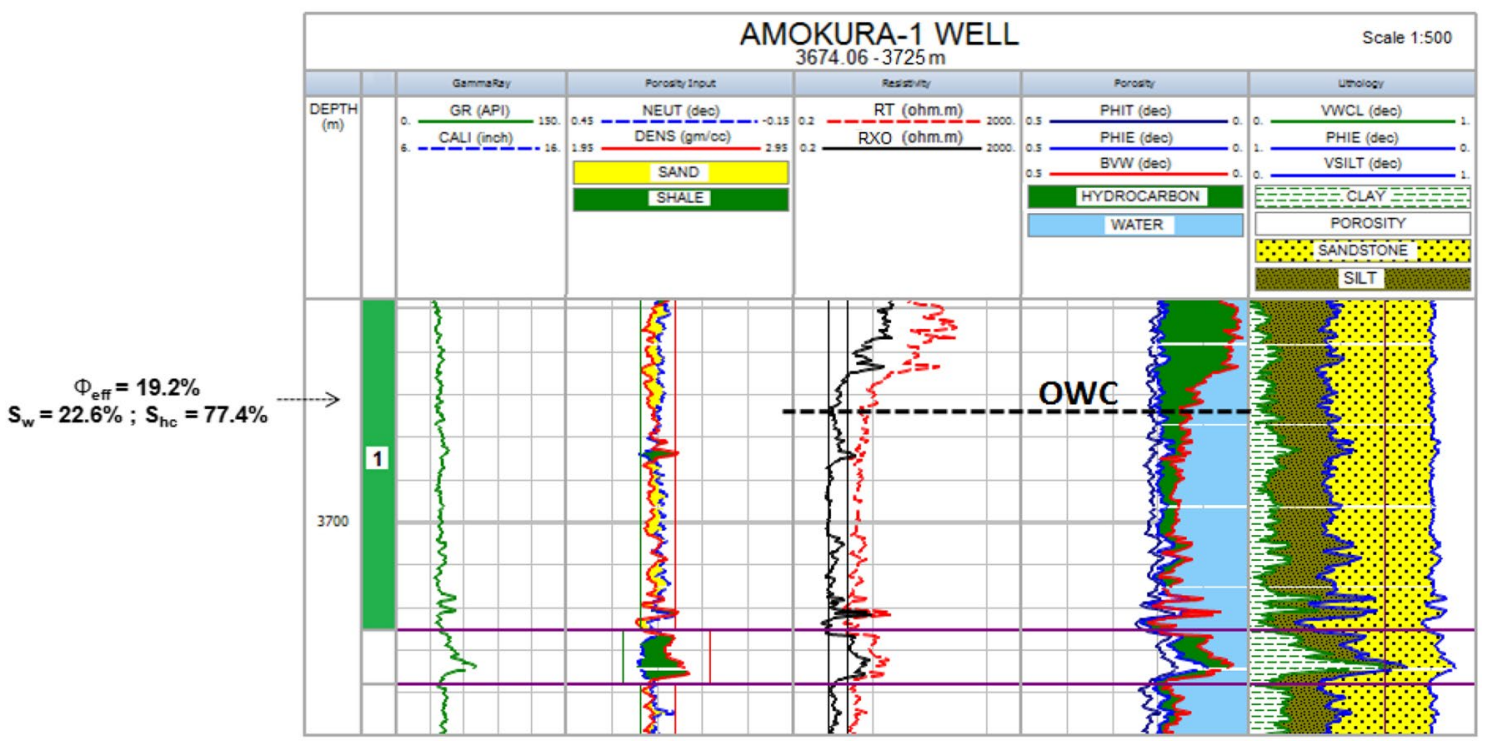

Fig. 15 Amokura-1 Well log interpretation shows one promising hydrocarbon-bearing pay zone with good resistivity separation

nature of the pore network formation determines the characteristics of the framework grains, such as grain size and sorting. These parameters in turn control porosity and permeability; textural features supporting good reservoir quality of a reservoir are coarse-grained sediments with good sorting. The Farewell Formation consists predominantly of sandstones which were deposited in fluvial braid plain and coastal plain (King and Thrasher 1996). Sediments with relatively coarser-grained texture are typical to such depositional settings. The grain size for Farewell Formation is generally of upper medium-grained nature, with at least moderate sorting (Table 2). This is in parallel agreement 
Table 2 Textural information of selected samples of Farewell Formation

\begin{tabular}{llllll}
\hline Well & Depth $(\mathrm{m})$ & Texture & & \\
\cline { 3 - 6 } & & Grain size (phi) & $\begin{array}{l}\text { Grain size } \\
\text { (class) }\end{array}$ & Sorting (phi) & Sorting (class) \\
\hline MB-R(1) & 3521.18 & 1.15 & $\mathrm{mU}$ & 0.55 & $\mathrm{MG}$ \\
& 3536.15 & 1.73 & $\mathrm{~mL}$ & 0.45 & $\mathrm{GO}$ \\
& 3564.8 & 1.10 & $\mathrm{mU}$ & 0.54 & $\mathrm{MG}$ \\
MB-W(2) & 4113.55 & 1.35 & $\mathrm{mU}$ & 0.63 & $\mathrm{MG}$ \\
& 4125.53 & 1.47 & $\mathrm{mU}$ & 0.51 & $\mathrm{MG}$ \\
& 4134.17 & 1.42 & $\mathrm{mU}$ & 0.47 & $\mathrm{GO}$ \\
Tui-1 & 3665 & 1.46 & $\mathrm{mU}$ & 0.58 & $\mathrm{MG}$ \\
& 3666 & 1.60 & $\mathrm{~mL}$ & 0.77 & $\mathrm{MT}$ \\
& 3668 & 1.76 & $\mathrm{~mL}$ & 0.94 & $\mathrm{MT}$ \\
& 3676 & 1.51 & $\mathrm{~mL}$ & 0.64 & $\mathrm{MG}$ \\
& 3677.5 & 2.03 & $\mathrm{fU}$ & 0.77 & $\mathrm{MT}$ \\
& 3690 & 1.77 & $\mathrm{~mL}$ & 0.81 & $\mathrm{MP}$ \\
& 3702 & 1.23 & $\mathrm{mU}$ & 0.59 & $\mathrm{MG}$ \\
\hline
\end{tabular}

Grain size classes $m U$ upper medium-grained, $m L$ lower medium-grained, $f U$ upper fine-grained

Sorting classes $G O$ good sorting, $M G$ moderately good sorting, $M T$ moderate sorting, $M P$ moderately poor sorting with the conclusion in this study, where the Farewell Formation sandstones have good porosity and permeability.

The Farewell Formation is the oldest known reservoir in Taranaki Basin (King and Thrasher 1996). The five wells selected under study collectively produce good reservoir quality of the Farewell Formation, thus confirming the Farewell Formation as an important reservoir unit in the petroleum system in Taranaki Basin.

MB-R(1), Rahi-1 and Maui-2 wells were used for subsurface stratigraphic correlation to see the lateral extension of the Farewell Formation reservoir in the Maui Field area (Fig. 2). It can be seen in the area that the Farewell Formation has a good lateral thickness between these wells, suggesting good hydrocarbon potentiality for drilling. The structural model developed by Eahsanul Haque et al. (2016) showed the Maui Field experienced various normal structures which affected Farewell reservoir unit and other overlying reservoirs (Kaimiro and Mangahewa) (Fig. 3). These faults are all thought to be sealing as they are producing reservoirs. The petroleum system in this area consists of stratigraphic trap where the seal is within the Farewell Formation itself (shale unit). Moreover, following the previous petrographic and petrophysical analyses, it can be confirmed that MB-R(1) Well contains hydrocarbons, making it a great prospect for drilling.

\section{Conclusions}

Based on the three components utilized in this reservoir characterization study of the Farewell Formation, it can be concluded that the Farewell Formation has good reservoir quality. The integrated study strongly supports the known role of the Farewell Formation as a proven reservoir in the petroleum system in Taranaki Basin. Based on petrographical and sedimentological analyses, the main diagenetic features observed throughout the formation are compaction, cementation, clay authigenesis and secondary porosity. While these features may coexist at any depth, porosity is more dominant in general and thus plays a deciding role in producing good reservoir quality. Overall, the porosity and permeability values show that a majority of the sample data points have at least good reservoir quality. The porosity and permeability values collectively have a positive relationship and permeability increases with increasing porosity. Well log analysis shows that the Farewell Formation is a promising reservoir with good effective porosity and low water saturation percentages, averaging at 17.7 and $24.9 \%$, respectively. Moreover, subsurface stratigraphic correlation between MB-R(1), Rahi-1 and Maui-2 within the Maui Field area shows a good lateral extent of the Farewell Formation reservoir.

Acknowledgements The authors would like to thank GNS Science for providing the data and information necessary for this research. The authors are also grateful to Universiti Brunei Darussalam for the University Graduate Scholarship (UGS) and for providing the facilities and resources to conduct the research. A token of appreciation is also extended to LR Senergy for the Interactive Petrophysics software.

Open Access This article is distributed under the terms of the Creative Commons Attribution 4.0 International License (http://creativecommons.org/licenses/by/4.0/), which permits unrestricted use, distribution, and reproduction in any medium, provided you give appropriate credit to the original author(s) and the source, provide a link to the Creative Commons license, and indicate if changes were made. 


\section{References}

Alotaby WD (2015) Fault interpretation and reservoir characterization of the Farewell Formation within Kerry Field, Taranaki Basin, New Zealand. Masters Thesis 7458, Missouri University of Science and Technology

Armstrong PA, Chapman DS, Funnell R, Allis RG, Kamp PJ (1996) Thermal modeling and hydrocarbon generation in an active-margin basin: Taranaki Basin, New Zealand. Am Assoc Pet Geol Bull 80(8):1216-1241

Bal AA (1994) Cessation of Tasman Sea spreading recorded as a sequence boundary: interpretation of an early Paleocene unconformity in the Pakawau sub-basin, northwest Nelson, New Zealan. In: Van Der Lingen GJ, Swanson KM, Muir RJ (eds) The evolution of the Tasman Sea Basin: proceedings of the Tasman Sea conference, Christchurch, New Zealand, 27-30 November 1992. Balkema, Rotterdam

Baur J, Sutherland R, Stern T (2014) Anomalous passive subsidence of deep-water sedimentary basins: a prearc basin example, southern New Caledonia Trough and Taranaki Basin, New Zealand. Basin Res 26:242-268

Blatt H, Middleton G, Murray R (1980) Origin of sedimentary rocks. Prentice-Hall, Englewood Cliffs

Cade CA, Evans IJ, Bryant SL (1994) Analysis of permeability controls a new approach. Clay Miner 29:491-501

Eahsanul Haque AKM, Islam MA, Shalaby MR (2016) Structural modeling of the Maui Gas Field, Taranaki Basin, New Zealand. Pet Explor Dev 43(6):965-975

Ehrenberg SN (1990) Relationship between diagenesis and reservoir quality in sandstones of the Garn Formation, Haltenbanken, mid-Norwegian continental shelf. Am Asso Petrol Geol Bull 74:1538-1558

Hakimi MH, Shalaby MR, Abdullah WH (2012) Diagenetic characteristics and reservoir quality of the Lower Cretaceous Biyadh sandstones at Kharir oilfield in the western central Masila Basin, Yemen. J Asian Earth Sci 51:109-120

Imam B (1986) Scanning electron microscopu study of the quartz overgrowths within Neogene sandstones of Bengal Basin, Bangladesh. J Geol Soc India 28:407-413

King P, Thrasher G (1996) Cretaceous-Cenozoic geology and petroleum systems of the Taranaki Basin, New Zealand. Institute of Geological and Nuclear Sciences monograph 13. Lower Hutt. Institute of Geological and Nuclear Sciences Limited, New Zealand

Knox G (1982) Taranaki Basin, structural style and tectonic setting. NZ J Geol Geophys 25:125-140

Kroeger K, Funnell R, Nicol A, Fohrmann M, Bland K, King P (2013) 3D crustal-scale heat-flow regimes at a developing active margin (Taranaki Basin, New Zealand). Tectonophysics 591:175-193
Levorsen AI (1967) Geology of petroleum. W.H. Freeman, San Fransisco

Loucks RG (2006) Revisiting the importance of secondary dissolution pores in tertiary sandstones along the Texas Gulf Coast. Guld Coast Assoc Geol Soc 55:447-455

Ministry of Business, Innovation and Employment, New Zealand (2014) New Zealand Petroleum Basins 2014/2015 Revised edition. New Zealand Petroleum and Minerals, Wellington, p 105

New Zealand Overseas Petroleum Limited (2004) Amokura-1 Well completion report. Ministry of Economic Development New Zealand Unpublished Petroleum Report PR2920

Palmer J, Geoff B, (1991) Taranaki Basin, New Zealand. In: Active Margin Basins, AAPG Memoir vol. 52, pp. 261-282

Pilaar WFH, Wakefield LL (1978) Structural and stratigraphic evolution of the Taranaki Basin, offshore North Island, New Zealand. Aust Pet Explor Assoc J 18:93-101

Schlumberger (1989) Log interpretation principles. Schlumberger Educational Services, Texas

Schmidt V, McDonald DA, Platt RL (1977) Pore Geometry and Reservoir Aspects of Secondary Porosity in Sandstones. Bul Can Petrol Geol 25(2):271-290

Shalaby MR, Hakimi MH, Abdullah WH (2013) Diagenesis in the Middle Jurassic Khatatba Formation sandstones in the Shoushan Basin, northern Western Desert. Geol J 49(3):239-255

Shalaby MR, Hakimi MH, Abdullah WH (2014) Petroleum system analysis of the Khatatba Formation in the Shoushan Basin, north Western Desert, Egypt. Arab J Geosci 7(10):4303-4320

Strogen DP, Roncaglia L, Crouch EM (2010) The Farewell Formation reservoir fairway: a study of Paleocene biostratigraph, facies development and reservoir quality in the Taranaki Basin, p 283. In: Hoksin P, Hikuroa D, Eccles K (Coveners), GeoNZ 2010: geoscience, geothermal: abstract volume: Auckland, 21-24 November 2010. Wellington: Geoscience Society of New Zealand. Geoscience Society of New Zealand miscellaneous publication 129A

Thrasher G (1992) Late Cretaceous geology of Taranaki Basin. PhD thesis, Victoria University of Wellington

Worden RH, Morad S (2000) Quartz cement in oil field sandstones: a review of the critical problems. In: Worden RH, Morad S (eds) Quartz cementation in sandstones, vol 29. International Association of Sedimentologists, Special Publication, pp 1-20

Worden RH, Morad S (2003) Clay minerals in sandstones: controls on formation distribution and evolution. In: Worden RH, Morad $\mathrm{S}$ (eds) Clay mineral cement in sandstones, vol 34. International Association of Sedimentologists, Special Publication, pp 3-41

Publisher's Note Springer Nature remains neutral with regard to jurisdictional claims in published maps and institutional affiliations. 